\title{
Factors Contributing to the New Trend of Buying From Supermarkets and Shopping Malls in Kenya
}

\author{
Wambugu Hannah $^{1^{*}} \quad$ Raymond Musyoka ${ }^{2}$ \\ 1.School of Business and Economics, Kirinyaga University, Kenya P.O Box 143-00100 Kerugoya, Kenya \\ 2.School of Business Administration, University of Nairobi, P.O Box 30197 GPO, Nairobi Kenya
}

\begin{abstract}
Although there are several studies done on the influence of situational, individual and marketing factors on consumer behavior in regard to the amount of commodities bought from retail outlets in the developed world and the emerging markets, there no comprehensive studies that really explains the growth of buying trends in the developing countries like Kenya. This study seeks to investigate what factors are contributing to the new trend of buying from supermarkets and shopping malls in Kenya. The study adopted a survey design on a sample of 1000 consumers in Nairobi, Ruiru, and Kiambu town, and data was collected using structured questionnaires. Regression analysis was used to show the actual effect of consumers' income, ownership of consumer durables (cars and fridges) (marketing factors (prices and exposure to promotion), Socio-psychological factors mainly family size and situational factors (physical environment and antecedent state and temporal situation) on the number of visits to the supermarkets and shopping malls. The results indicated that all the situational factorstime of the day (day time), time of the week, supermarket atmospherics, supermarkets location and antecedent states (excitement) had significant effect on consumer behavior in terms of the number of visits to the supermarkets per month. However, the effect of time of the day (day time) though significant was negative (coeff -.0250 , p-value 0.000 ), an indication that number of times was lower by 0.250 for shoppers doing shopping during the day compared to shopping in the evening. All personal factors except for the age had positive and significant effect on the number of visits to the supermarkets/shopping malls. Perceiving of prices charged by supermarkets as low and exposure to supermarkets existence through advertising and promotions had positive and significant effect on visits to the supermarkets and shopping malls in Kenya. This implied that personal, situational and marketing factors are explaining the new trend of shopping in supermarkets in Kenya. The results also imply that, the investors in large-scale retail business in Kenya have to choose their location carefully away from CBD of the major cities and the pricing strategies have to be well planned because despite the fact that Kenyan consumers are shopping from super markets, they are cash-constrained.
\end{abstract}

Keywords: Supermarkets, Personal Characteristics, Situational Factors and Socio-psychological Factors DOI: $10.7176 / \mathrm{EJBM} / 11-3-08$

\subsection{Introduction}

Consumer shopping behavior is a fundamental issue in marketing that marketers should not ignore if they are to succeed in the competitive business environment. (Wambugu 2014). Knowledge of the outcome of consumer shopping behavior assists firms when planning and implementing their marketing strategies (Saleemi, 2011). Manufacturers and other marketers also use this knowledge to predict how consumers will respond to marketing strategies including market segmentation strategies (Kibera \& Waruingi, 2007). Paul \& James, (2007) emphasizes that the better the firms understands the outcome of consumers' shopping behavior, the more likely they become successful in the market place. Furthermore, the firm's marketing strategies should address questions related to what products customers buy, when they buy and why they buy them. This is the only way a firm can succeed in increasing product adoption and repeat purchase (Wambugu and Musyoka, 2015).

Globally, the behavior of consumers of manufactured and agricultural products has been changing in regard to choice of retail outlets they visits. In Europe and USA, consumers purchases all consumer goods) including agricultural products from supermarkets and shopping malls, unlike in Africa where consumers have attendances to buy their consumer products from supermarkets but for agricultural goods, they visit open air markets. However, in Kenya the consumer's shopping trends are changing where doing their shopping for all consumer goods (including agricultural products) in supermarkets and shopping malls(Wambugu 2014). Based on the Kenya branch of international retail auditor ACNielsen, the term refers to self-service retail stores handling fastmoving consumer goods (FMCG) in large scale. It therefore includes stores with at least 1625 square feet of floor space. Retail supermarkets with floor space larger than this are referred to as hypermarkets.

Large scale retail trade in form of supermarkets started in Kenya in 1960's. The old players in the large scale retailers business include: Uchumi, which was founded in the mid 1970's and Nakumatt supermarkets founded in 1987 (Kamau, 2008). The growth of supermarkets was rather slow in 1970s and 1980s. However, much growth was registered in 1990s (Irungu \& Wanjau, 2011). Using the definition presented above, there are roughly 209 supermarkets and 16 hypermarkets in Kenya. Further, an estimated 900 to 1400 smaller self-service shops entered the retail sector by 2005 (Neven \& Reardon, 2005). These shops include mini-supermarkets found 
in small towns, residential areas of major towns and at petrol (gas) stations. The emergence of self-selection stores marks the departure from the traditional shopping experience at small kiosks, single shops and open air markets.

Until recently, the dominant players in the sector included Nakumatt with 19 branches spread in Kenya, while 2 out of the 19 are located outside Kenya; one in Uganda and another in Rwanda (Riungu et al, 2013). Some of the Nakumatt stores used to open round the clock. Tuskys supermarket has been ranked second in terms of sales in the retail industry, while Uchumi despite being the oldest and once leading is ranked the third. However, since 2017, Nakummatt has experienced financial difficulties and has closed most of its branches and its position has has been taken by Tuskeys supermarket. Other key players are Naivas supermarkets and Chandrarana (Irungu \& Wanjau, 2011; Kamau, 2008). Other regional supermarkets include, Mathai supermarket, Maguna, Clean Shelf, Kamindi supermarkets and many more. International players such as Game, and Choppies have also entered Kenyan market.

With such a huge number of supermarkets, Kenya is the second country in Africa after S. Africa in terms of presence of supermarkets. Between 1993 and 2003, Kenya registered 18-20\% growth in number of supermarkets (Riungu, Njehia \& Mutai, 2013). Previously, supermarkets were concentrated in the CBD of major cities: Nairobi, Mombasa, Nakuru, Eldoret and Kisumu. However, the supermarkets are spreading from the town CBDs to the wealth suburbs of those cities and to smaller towns particularly in the metropolitan towns. Big shopping malls are also springing up in the wealth suburbs. National Economic Survey (2012) identified the retail and wholesale trade as key growth drivers of Kenya's economy (GoK, 2012).

Despite the growth witnessed in the large scale retail businesses in Kenya, little research has been done to identify various reasons why consumers are currently buying consumer and sometimes producer goods from supermarkets in Kenya. According to Irungu \& Wanjau, (2011), market liberalization and urbanization has led to increased competition in the retail sector, heightening the growth of supermarkets in Kenya. However, there is need to investigate the specific reasons why consumers in Kenya are of late buying consumer goods from supermarkets and shopping malls.

This study seeks to analyze the factors influencing the consumers' behavior towards supermarkets and shopping malls in Kenya. Specifically, the study seeks to investigate:

i) The extent to which personal characteristics ( education, age, gender income and ownership of consumer durables) influences their shopping behavior in supermarkets

ii) Whether marketing factors (prices and exposure to existing supermarkets through advertising and other forms of promotions) influences consumers shopping behavior in supermarkets

iii) The extent to which situational factors (physical environment, antecedent state and temporal situation) influences consumers shopping behavior in supermarkets

iv) Whether Social-psychological Factors (Family size) influences consumers shopping behavior in supermarkets

\subsection{Literature Review}

\subsection{Theoretical Literature}

The American Marketing association defines consumer behavior as 'the dynamic interaction of affect and cognition, behavior and the environment by which human beings conduct the exchange aspect of their lives' (Paul \& Olson, 2008). In other words, consumer behavior involves the thoughts and feelings that people experience and the actions they perform in consumption process. It also includes all the things in the environment that influence these thoughts, feelings and actions (Jobber, 2010). According to Jobber (2010), the study of the buyer behavior 'involves understanding of how individuals or organizations behave in the purchase situation'. Consumer behavior is dynamic because the thinking, feelings and actions of individual customers are constantly changing (Hoyer \& Maclinnis, 2011). This highlights the importance of studying consumer behavior. It is the only way through which marketers can keep abreast of the important trends in the market

\subsubsection{Factors influencing Consumer Buying Behavior}

Consumers do not exist in a vacuum. They live and interact with the environment surrounding them. Thus, there are factors within them that dictates how they behave towards products and services, and there are other factors that are external.

\section{Customer Individual Characteristics}

According to Kotler, et al (2009), Customer individual characteristics are these factors particular to an individual. They are classified into seven categories:

i) Customer's age and stage in his life cycle: This factor influences purchase decision in that, individuals buy different goods and services over a life-time (Rajan, 2006). Taste in food, clothes, furniture and recreation is often age related. Trends like delayed marriages, children migrating to distant cities or abroad for work leaving parents behind, tendency of professionals/ working couple to acquire assets such as a house or an automobile in the early stage of career (earlier these used to be close-to- retirement acquisitions for a large majority) has 
resulted in differently opportunities for marketers. It is also important that, marketers considers critical life events or transitions- marriage, childhood, illness, relocation, divorce, career change, widowhood- as giving rise to new needs.

ii) Gender: Gender has been defined as the fact of being male or female (Hornby, (2010 p.g 619). Consumers buy different goods and services depending on their gender (Kibera \& Waruingi, 2007). Taste and preferences for goods and services is often gender related. As a result, gender has been used as one of the criterion for segmenting the market for goods and services.

iii) Consumer's level of education: This factor determines the occupation of an individual. Consumer's occupation influences consumption patterns as items required by different types of workers differ. For instance, a blue-collar worker will buy work clothes, work shoes and lunchboxes, while a company president will buy dress suits, air travel and country club memberships (Jobbar, 2010). Marketers should always identify occupational groups to target with their goods/ services.

iii) Consumer's level of income: Individual's buying power is directly proportional to income/earnings. Income determines how much an individual spends and on which products. High income individuals are likely to buy expensive and premium products while middle and lower income individuals tend to spend mostly on necessary items (Blackwell et al, 2009).

iv) Customer's Personality: According to Kotler, et al (2009), personality refers to a set of distinguishing human psychological traits that lead to relatively consistent and enduring responses to environmental stimuli. Chauhan (1992) defines personality as a pattern of behavior founded on an individual's outlook and internal traits, which is made up the characteristic patterns of thoughts, feelings and behaviors that make a person unique. (Blackwell et al, 2009).

v) Customer's Lifestyle: Individuals from the same subculture, social and occupation may lead quite different lifestyles (Paul \& James, 2007). Blackwell et al, (2009) defines lifestyle as a person's pattern of living in the world as expressed in activities, interests, and opinions. It captures the "whole person" and how the person is interacting with his environment. According to Kibera \& Waruingi (2007), lifestyle refers to the way an individual stays in the society. For instance, an individual living in a posh locality needs to maintain his status and image, by buying specific brands and shopping in certain retail outlets.

vi) Perception: Although psychologists make a distinction between sensation and perception, it may not always be clear where sensation ends and perception begins (Mwangi, 2009). The way individuals perceive the environment may either influence or change their thinking. Their confidence in things is determined by their perception.

Marketing influences

Marketing influences refer to marketing mix elements which include: product attributes (quality and packaging), promotion, place and price (Saleemi 2011; Kibera \& Waruingi, 2007). Promotion greatly influences consumers' information processing level. Psychologists divide human information processing into various stages. One such division includes successive levels of exposure, perception, comprehension, retention, retrieval, decision making and action. Depending upon the stage, influence on behavior will vary (Paul \& James, 2007If the consumer has a lot of information concerning the product and is convinced it is the best, knows where to buy it, how much it costs, he may purchase it without searching for additional information (Paul \& James, 2007).

Situational Factors

Those are factors distinct from personal or product factors. According to Keneth (1974), behavior should be measured under similar situational conditions. Belk (1975) defined consumer situation as; "all those factors particular to time and place of observation which do not follow from knowledge of personal (inter-individual) and stimulus (choice alternative) attributes, and which have a demonstrable and systematic effect on current behavior". Lutz \& Kakkar (1975) expanded on Belk's (1975) definition to include the effects of situation on individual's psychological processes and overt behaviour. According to Melissa (1995), further distinction of situational variables can be made according to the type of situation being either purchase situation, communication situation or usage situation.

According to Hawkins et al, (2007), 'situational factors include stimuli in the environment of other than the focal stimulus, and temporary characteristics of the individual. Pride et al, (2008 p.g 230) viewed situational influences as factors that results from considerations of time and location that influence consumer buying decision process. In this study, the definition by Belk, 1975 is adopted and the purchase situation is focused on Belk's (1975) theory identified five categories of situational factors that can influence consumers purchase decision, which include:

Temporal situation - refers to the time dimension of shopping situation. It may be specified in units as time of day or season of the month/year when individual shops. It can also be measured relative to some past or future event for the participant. This allows such conceptions as time since last purchase, time since payday, and time constraints imposed by prior or standing commitments.

Task feature of a situation - it is the reasons or goals that occasion the need for consumers to buy or 
consume a product or service.

Antecedent state - it is the current condition of the customer in the buying situation', which are different from chronic individual traits, and may be perceived either consciously or sub consciously. It includes momentary moods (such as acute anxiety, pleasantness, hostility and excitement) or momentary conditions such as cash available during purchase, fatigue and illness.

Physical environment situation - it is 'the readily apparent features of a buying situation. These features include geographical and institutional location, sounds, aroma, proximity of objects to other objects and instruments. Researchers have also included other elements such as product, exhibits or other materials and retail store design and layout to this category (Pride et al, 2008).

Social features - those are 'the shopper's interactions with other persons present during purchase". It may refer to the presence or absence of other persons and their roles during the shopping activity. The presence of other persons during purchase may influences consumer behavior positively because customers feel that those around them will view them more positively if their purchases show more variety. However, social surrounding influences on purchase decision are associated with consumers who are easily influenced by others (Ratner, 2002).

\section{Theoretical Framework}

Figure 1: Theoretical Framework

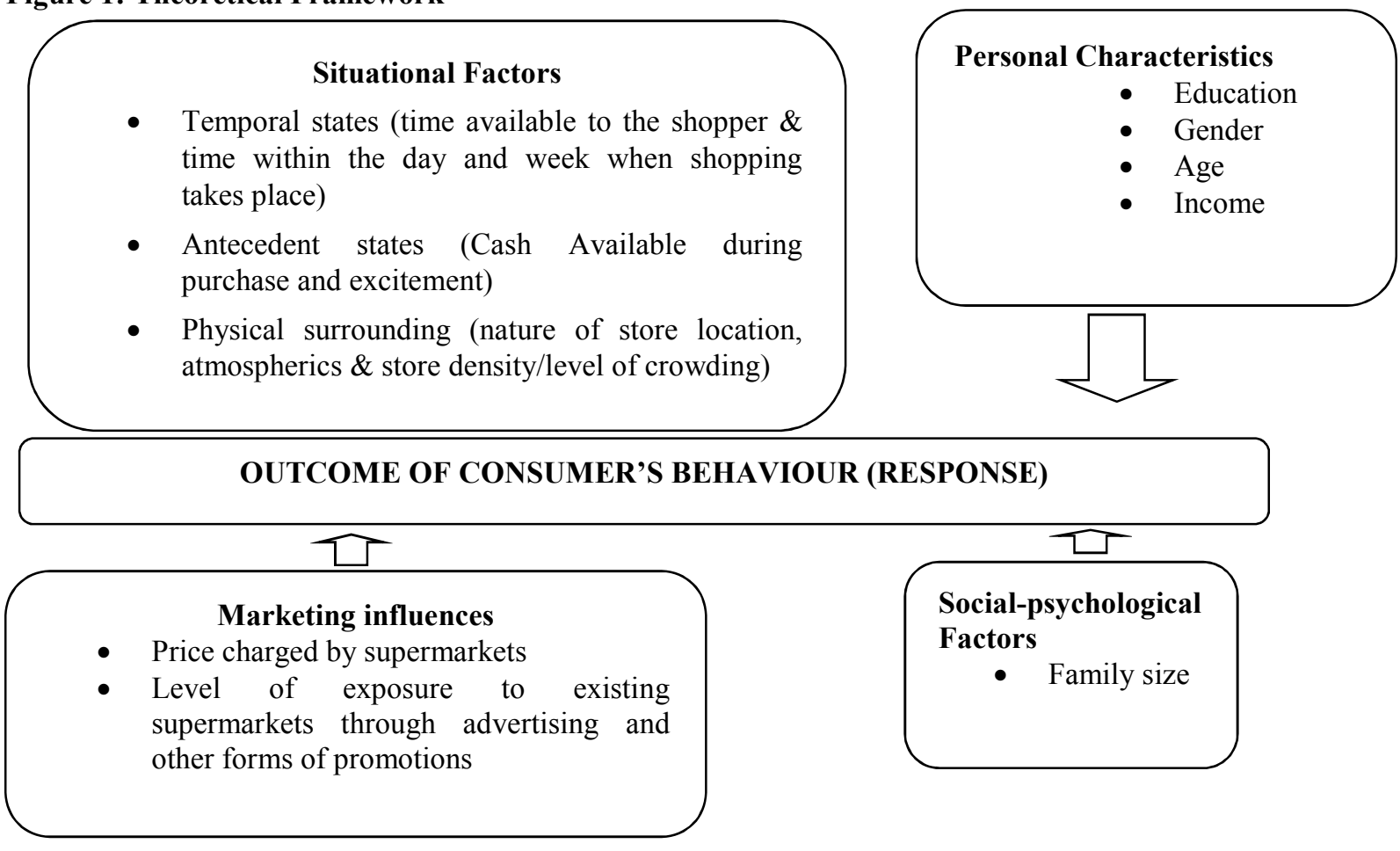

\section{Empirical literature}

Machleit et al, (2000) examined crowding in retail stores and its relationship with customer satisfaction. The aim was to establish whether this relationship was simple, and direct or not. The study specifically considered the possibility that the relationship between crowding and satisfaction is mediated by emotional reactions that are experienced while shopping. In addition, moderating variables such as prior expectations of crowding, tolerance for crowding and store type were examined for their influence on relationship between crowding and customer satisfaction. From the results of the two fields of studies, it was observed that, whereas emotions only partially mediate the relationship, the decrease in shopping satisfaction due to crowding can be moderated by expectations of crowding and personal tolerance for crowding. An experiment replicated the two fields of study and its results indicated that the relationship between perceived store crowding and shopping satisfaction varied by shopping store.

A study by Tan (2002) investigated the relationship among situational factors, price perceptions and purchasing outcomes in Klang Valley. The findings of the study showed that social shoppers, the day shopping, capture time, shopping day, use of shopping list, way of shopping, and number of store patronized, tend to positively influence price mavenism, and price consciousness which finally impacts on purchasing outcomes.

Zhuang et al, (2006) studied the impact of situational factors on buying decisions in shopping malls in USA, China and Hong Kong. The findings of this study indicated that task definition, social surrounding, temporal 
features and antecedent states significantly affected shopper's purchase behavior for food and non-food products. However, the effect of situational factors differed according to the products purchased

Anic \& Radas (2006) applied Belk's model (1975) to investigate the impact of situational factors on the purchase outcomes in Croatian supermarkets. The outcome of behavior was measured in terms of items bought and money spent. The findings of this study indicated that social surroundings, high perceived store density and large scale shopping were factors that significantly contributed to higher level of purchasing outcomes. However, based on One-way Anova, the study did not find significant difference in purchasing outcomes among shoppers grouped according to store atmospherics. However, early shoppers, slow-shoppers and distant shoppers had significantly more purchases.

Another study on effect of situational factors on purchase decision process was by Docrat (2007). He conducted a study among shoppers at various shopping centres in Durban South Africa. The study confirmed the significance of various situational factors mainly, physical surrounding, social surroundings, time available, task definition and the antecedent states (mainly cash available during purchase), as they impact on shoppers during shopping activity. However, the generalization of the findings of this study can be limited by the fact that it targeted only the English speakers in Durban. One wonders whether similar results could be achieved if everyone else in Durban participated in the study.

A study by Heidarizade \& Teherikia (2010) investigated the causes of impulse buying in supermakets, in Iran. The results of this study indicated that money available during purchase influences outcome of behaviour. However, money available during purchase does not have positive effect on the shopper's moods. The findings contradicted the findings by Beatty \& Elizabeth (1998) who had found in their study that, the money available to the individual during shopping has a positive effect on the mood of the shopper, which then affects outcome of behavior positively.

Amir et al (2012) investigated the influence of situational factors (money and time available) on impulse buying behavior among different ethics in Malaysia. Results revealed that the situational variables (money available and Time available) were influence to the felt urge to buy impulsively and impulse buying. Beside that positive affect has mediating role between situation variables and impulse buying.

Wambugu (2015) investigated the influence of situational factors and milk packaging characteristics on the amount of milk bought from supermarkets in Kenya. The findings made her conclude that Kenyans buy more processed milk for other purposes such as making tea/coffee and baking compared to when buying for drinking directly from the pack and that the presence of companions is a good predictor of outcome of behavior in regard to the amount of processed milk bought from supermarkets in Kenya during a shopping activity. Her study also found that long stay at the milk stand enhances outcome of behavior in regard to the amount of milk bought from supermarkets in Kenya and that time of the day (morning) had a negative effect on the amount of milk bought from supermarkets in Kenya. Other finding were that, being cash constrained during shopping had a negative but significant effect on the amount of milk bought. Another conclusion was reached that consumer's perceived importance for packaging characteristics influences the outcome for milk purchase behavior. For the controlled variables in her study, she found that, gender had a significant effect where more milk was bought if respondent was a male, age had positive but insignificant effect, education, family size and income had positive effect on the consumer behavior. However the study was based on the consumer behavior manifestation in regard to amount of milk bought but it would be interesting to see whether the same variables has significant effect on number of times a consumer visits the supermarket or shopping malls in order to understand the factors responsible of growth of supermarkets in Kenya. 
Fig 2 Conceptual Framework

\section{Situational Factors}

- Temporal states (time within the day and week when shopping takes place)

- Antecedent states (Cash Available during purchase and excitement)

- Physical surrounding (nature of store location, atmospherics \& store density)

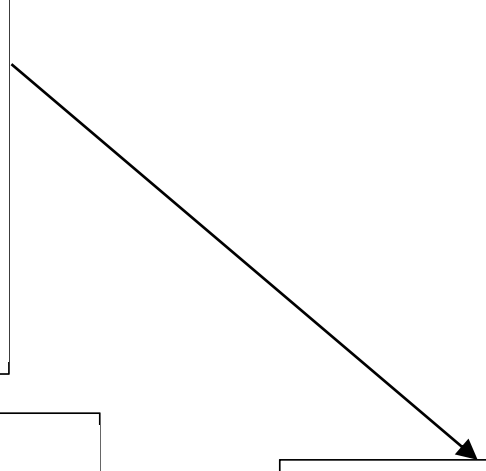

- Education, Gender, Age \& Income

- Ownership of consumer durables

- Female participation in labor force

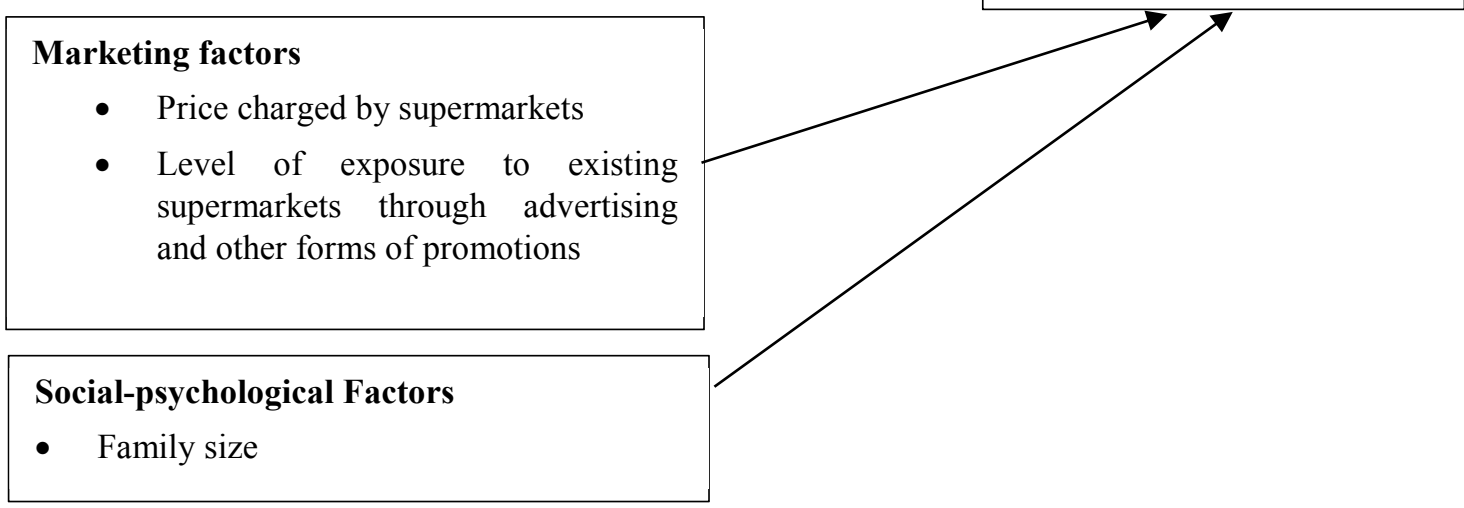

\subsection{Research Methodology}

Survey design was adopted for this study, and a sample of 1000 consumers in Nairobi, Ruiru, and Kiambu town was used, where primary data was collected using structured questionnaires. Regression analysis was used to show the actual effect of consumers' income, ownership of consumer durables (cars and fridges) (marketing factors (prices and exposure to promotion), Socio-psychological factors mainly family size and situational factors (physical environment and antecedent state and temporal situation) on the number of visits to the supermarkets and shopping malls.

\subsection{Results}

The results indicated that $65 \%$ of shoppers interviewed were men, and 785 of all shoppers had over 16 years of education. 98\% of shoppers were earning over Ksh 20,000. The results further indicated that, $20 \%$ of the respondents visited supermarkets and shopping malls during the day, while $70 \%$ visited those shopping venues over the week-end. $88 \%$ of the respondents indicated that they preferred shopping in the supermarket in the suburbs, (mainly near their residence estates). On the other hand, 70\% felt that they are usually cash constrained, and the reason as to why they shop in the supermarkets. $72 \%$ of the women supermarket shoppers interviewed indicated that they are participating in labor force, either as office employees or in business. $98 \%$ of the respondents perceived supermarkets' prices as fair compared to prices charged on manufactured goods by single shops and kiosks. However, the agricultural products were considered highly priced by $90 \%$ of the respondents, compared to the prices charged in the kiosks and open-air market. 
Table 1. Estimation of the Full Regression Model

\begin{tabular}{|c|c|c|c|c|}
\hline \multirow{6}{*}{\multicolumn{2}{|c|}{ Linear regression }} & No.obs & $=$ & 1000 \\
\hline & & $F(15,984)$ & $=$ & 410.20 \\
\hline & & Prob $>F$ & $=$ & 0.000 \\
\hline & & R-squared & $=$ & 0.792 \\
\hline & & Adj R-Squaired & & 0.789 \\
\hline & & Root MSE & $=$ & 0.367 \\
\hline & Coef. & Std.Err & $\mathrm{t}$ & $\mathrm{P}>\mathrm{t} \quad[95 \%]$ \\
\hline Time of the day(day time) & -0.250 & 0.025 & -10 & 0.000 \\
\hline Time of the week (week-end) & 1.008 & 0.0673 & 4.621 & 0.000 \\
\hline Supermarket Atmospherics & 1.263 & 0.023 & 11.63 & 0.000 \\
\hline Outside town(CBD) & 1.144 & 0.031 & 4.72 & 0.000 \\
\hline Antecedent states (excitement) & 0.113 & 0.030 & 3.767 & 0.000 \\
\hline Cash-constrained & -0.114 & 0.035 & -3.257 & 0.000 \\
\hline Female participation in labor force & 1.119 & 0.025 & 4.69 & 0.000 \\
\hline Shopper's Gender & 0.240 & 0.025 & 9.76 & 0.000 \\
\hline Shopper's age & 0.001 & 0.002 & -0.22 & 0.828 \\
\hline Shopper's years of education & 1.008 & 0.006 & -1.25 & 0.113 \\
\hline Shopper's Family size & 2.038 & 0.014 & 2.66 & 0.008 \\
\hline Income & 3.0004 & 0.0000 & 1.31 & 0.090 \\
\hline Price Perception(low) & 1.0003692 & 0.000 & 1.15 & 0.050 \\
\hline $\begin{array}{l}\text { Exposure to existing supermarkets } \\
\text { through advertising and other forms } \\
\text { of promotions (high) }\end{array}$ & 1.0004 & 0.0000 & 1.03 & 0.190 \\
\hline cons & 1.2004 & 0.0961 & 10.49 & 0.000 \\
\hline
\end{tabular}

The results in table 4.8 indicate that, the coefficient of determination (R-Squared) is 0.792 . This implies that about $79.2 \%$ of the variation in visits to supermarkets could be explained by the combined action of the predictors in the model. F $(15,984)$ was 410.20 and with significance of 0.000 . Thus, the probability of these results occurring by chance was less than 0.05 . Therefore, a significant relationship was present between the number of visits to supermarkets and the independent variables. RMSE was 0.367 , an indication of a higher degree of goodness of fit of the regression model. All the independent variables except for age had significant effect.

\subsection{Conclusions and Recommendations}

From the results presented above, conclusions are made that situational factors have positive effect on the visits to the supermarkets. It can be noted that Kenyan consumers are currently doing their shopping in supermarkets outside CBD of major towns and more so are excited by the idea of buying from the supermarkets. This is an opportunity for investors to exploit, but they should be careful where to locate their supermarkets or shopping malls. It can be observed that most of the shoppers are cash constrained, thus pricing strategy of the products stocked should be done with this consideration in mind. Women participation in labour force is influencing the shopping in supermarkets and shopping malls positively. The supermarket should increase the ready to cook and ready to eat items and other items attracting working women. Exposure to existing supermarkets through advertising and other forms of promotions is also contributing positively to the new trend of buying from the supermarkets. This is in line with the marketing theory. The investors in the large -scale retail business in Kenya should budget for advertising and promotions in order to survive in this competitive sector. It can also be concluded that all personal characteristics of the consumer apart from age are contributing positively to the growing trend of buying from the supermarkets.

\section{References}

Amir, F., Buang, N.A. \& Sadeghi R. H. M. (2012), Exploring the influence of Situational Factors (Time \& Money Available) on Impulse Buying Behaviour among different Ethics. International Journal of Fundamental Psychology \& Social Sciences ISSN: 2231-9484

Angelica, O., Eisenhauer, L.\& Wyhaden, D. (2000), Ethics in Qualitative Research: Journal of Nursing Scholarship 33:1, 93-96

Anic, I. D \& Radas, S. (2006), The impact of Situational Factors on Purchasing Outcomes in the Croatian Hypermarket, retailer, EKONOMISKI PREGLED, 57(11): 730-752

Beatty, S. E \& Elizabeth F. M. (1998), Impulse Buying: Modeling its Precursors. Journal of Retailing, Vol. 74(2): 169-191 
Belk, R.W. (1975), Situational Variables and Consumer Behavior; Journal of Consumer Research Vol. 3: 151164

Blackwell, R. D., Miniard, P.W.\& Engel, J. F. (2009), Consumer Behavior $9^{\text {th }}$ Edition, Cengage Learning Products, McGraw-Hill; Harcourt College Publishers, London

Bruce, W.T. (2006), The Rapid Rise of Supermarkets? Development Policy Review 24(2):163-174, Overseas Development Institute, Blackwell publishing, Oxford 0X4 2DQ UK

Burns, A.C. \& Bush, R.F. (2006), Marketing Research, Fifth Edition, Pearson Education, Inc ISBN 81-3170937-X, Dorling Kindersley (India)

Chauhan, S. S. (1992), 'Advanced Educational Psychology' $3^{\text {rd }}$ Edition Vikas Publishing, New Delhi India

Cherukuri, J. (2010), Effect of Situational Factors on Store Format Choice Behaviour in Food Format Choice Behaviour in Food and Grocery Retailing in India - Multiple Discriminant Analysis IBSU Scientific Journal 2010, 4(2), 5-33

Enneking, U., Newmannn, C. \& Heneberg, S., (2007), 'How important Intrinsic and Extrinsic Product Attributes affect Purchase Decision' Food Quality Preference, 18:133-138

ESADA, (2010), Consumer Milk Quality Perception/Preferences and an Assessment of Willingness to Pay for Quality, Land 'Lakes Inc. Westlands, Nairobi

Government of Kenya (2012), Economic Survey Government Printers, ISBN 9966-767-41-X

Hawkins, D.L., Mothersbaugh, R. \& Best, J. (2009), Consumer Behavior; Building Marketing Strategy, $10^{\text {th }}$ Edition McGraw Hill College, Najafarh India

Heidarizade, K. \& Teherikia, F. (2010), The causes of Impulse Buying, Evaluation a Model in Iran. Journal of Management Research Vol. 21(85):43-63

Hornby, A. S. (2010), Oxford Advanced Learner's Dictionary of Current English, Oxford University Press, Oxford, New York, ISBN13:978-4-9:194516583

Hoyer, W.D. \& Maclnnis, D.J. (2011), Consumer Behavior, a Marketing Tool, Cengage Learning, Patparganj, India

Irungu, B.K. \& Wanjau, K.L (2011), Effectiveness of Vendor managed Inventory Systems in Retail Supermarkets in Kenya; Journal of Business and Public Management (ISSN: 2223-6244) Vol.1:85-89

Jobber, D. (2010), Principles and Practice of Marketing, Sixth Edition, McGraw-Hill Education, Shoppenhangers Road, Maidenhead Berkshire, United Kingdom

Kamau, F. (2008), The growth of Supermarkets in Kenya; Opportunities and limitations for pineapple producers; Conference Presentation, Esami, Nairobi, Kenya

Kardes, F. R., Maria, C.L., \& Thomas, W. (2011), Consumer Behavior, Mason, OH: South-Western, Cengage Learning

Kenhore, P.V, De Wulf, K. \& Watersoot, W.V. (1999), 'The impact of task destination on store attribute, salience and store choice', Journal of Retailing, Vol 75 No1, pp125-37

Kibera, F. N. \& Waruingi, B.C. (2007), Fundamentals of Marketing: An African Perspective. Kenya Literature Bureau, Nairobi

Kotler, P. (2002), Marketing management, $11^{\text {th }}$ Edition, Prentice-Hall London

Kuester, S. (2012), Strategic Marketing and Marketing in Specific Industry contexts: Marketing Course 401 Notes: University of Mannneim, Germany p.g.110

Lyer, K. \& Easwar, S. (1989) "unplanned purchasing knowledge of shopping environment and time pressure" Journal of Retailing 65(1): 40-57.

Lutz, R. J. \& Kakkar, P. (1975), The psychological situation as determinant of Consumer Behavior, Journal of Consumer Research vol.2, pp.439-453

Neven, D. \& Reardon, T. (2005), The Rise of Kenyan Supermarkets and the Evolvement of their Fresh Fruits and Vegetables Procurement Systems; Staff paper 2005-03, Department of Agricultural Economics, Michigan State University

Nicholls, J. A. F., Roslow, F. S., Dublish, S. \& Lucette, B. C. (1996), Relationship between Situational Variables and Purchasing in India and the USA, Journal of International Marketing Review Vol. 13 No.6 pp 6-21

Paul, J.P \& Olson, J.C. (2008), Consumer Behavior and Marketing Strategy, McGraw-Hill, Irwin 1221 Avenue of the Americans, New York, NY 10020

Riungu, C.K., Njehia, B.K. \& Mutai, B. K. (2013), Effects of Supermarkets on Fresh fruits and vegetables Small-Scale farmers in Central Kenya, Sky Journal of Business Administration and Management vol.1(5), pp. 47-58

Roslow, S. Li T. \& Nicholls, A. F. (2000), The impact of situational variables and Demographic Attributes in two Seasons on Purchase Behavior European Journal of Marketing (34) 9/10/ 1167-1180

Saleemi, N.A. (2011) Marketing simplified, Saleemi Publications Ltd, Nairobi, Kenya.

Sgangenberg, E. R. \& Yalch, R. F. (2000), The effect of Music in Retail Setting on Real and Perceived Shopping Times; Journal of Business Research, 49:139-147 
Sherman, E.M., Mathur, A. \& Smith, R.B. (1997), Store Environment and Consumer purchasing Behaviour, Journal of Psychology and Marketing Vol. 14 (4):361-78

Tan, C. G. (2002), Exploring the Relationship among situational factors, price preceptors and purchasing outcome in Klang Valley: Masters Thesis; University of Herefordshire Hertford Herts, United Kingdom

Turley, L.W. \& Milliman, R.E. (2000), “Atmospheric Effect on Shopping Behaviour' A Review of Experimental Evidence: Journal of Business Research Vol. 49:193-211

Zhuang, G., Tsang, A.S.L, Zhou, N., Li, F. \& Nicholls, J.A.F (2006), Impact of Situational Factors on Buying Decisions in Shopping Malls" European Journal of Marketing Vol. 40 (1/2): 17-42 